\title{
NOVÉ SBÍRKOVÉ AKVIZICE V KNIHOVNĚ NÁRODNÍHO MUZEA V ROCE 2020
}

V roce 2020 se podařilo výrazně obohatit sbírku kramářských tisků Knihovny Národního muzea, která svým rozsahem nemá v České republice obdoby. Fondy autorských štočků a ilustrací byly doplněny o současnou tvorbu. Neméně zajímavé jsou nově zakoupené provenienčně hodnotné staré tisky. Knižní fondy základní knihovny byly rozšířeny o malý fragment původní knihovny spisovatele Karla Václava Raise.

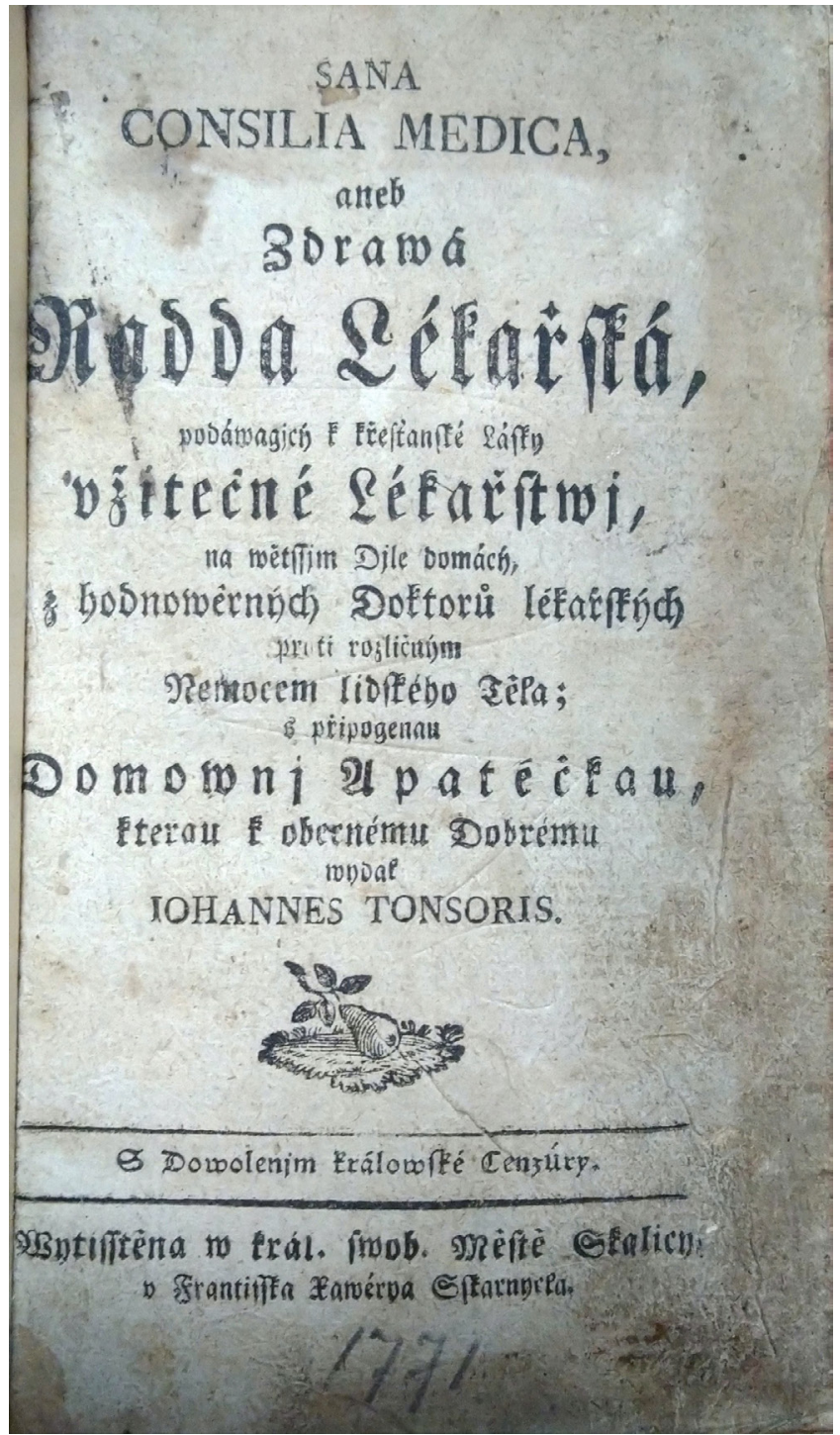

Obr. 1. Sana consilia medica, aneb Zdrawá radda lékařská od Jána Tonsorise vydaná okolo roku 1806 Františkem Xaverem Škarniclem v Uherské Skalici. Jedná se o jediný exemplár̆ dochovaný na našem území.
Pro oddělení rukopisů a starých tisků Knihovny NM byl $\mathrm{v}$ roce 2020 nejdříve zakoupen od Zuzany Topiarzové z Jílového u Prahy starý tisk Jána Tonsorise Sana consilia medica, Aneb Zdrawá radda lékařská, vytištěný u Františka Xavera Škarnicla v Uherské Skalici pravděpodobně v roce 1806. Na českém území se jedná o naprostý unikát, jelikož Knihopis eviduje pouze jeden exemplář ve Slovenské národní knižnici v Martině.

V závěru roku byly od antikváře Jana Placáka zakoupeny dva provenienčně hodnotné tisky, první La vie de Voltaire..., vydaný v Ženevě v roce 1786, který měl původně v majetku Johann Baptist hrabě Orlik z Laziska (1750-1811) a byl součástí zámecké knihovny Solca rodu Larisch-Mönnich, a pak vícesvazkové dílo Historia ecclesiastica Veteris Novique Testamenti Alexandra Noëla, vydané v Benátkách v roce 1771 a zakoupené v roce 1780 pro knihovnu mnichovohradišt'ských kapucínů z fundace Marie Markéty hraběnky z Valdštejna, rozené Černínové (1689-1725).

Jedinečná sbírka kramářských tisků v oddělení knižní kultury se rozšírila především díky nákupu souboru tří špalíčků kramářských písní a 235 samostatných kramářských písní z 18. a 19. století od Johna Bartoše ze Štramberka. Ten měl původně v držení sběratel MUDr. Leopold Bartoš.

Dalších 8 nově získaných kramářských tisků z let 1815 až 1868 pochází z pozůstalosti spisovatele Radovana Krátkého. Vesměs se jedná o morytáty, zajímavý je zvláště tisk z roku 1849 o lynčování uherského vrchního velitele

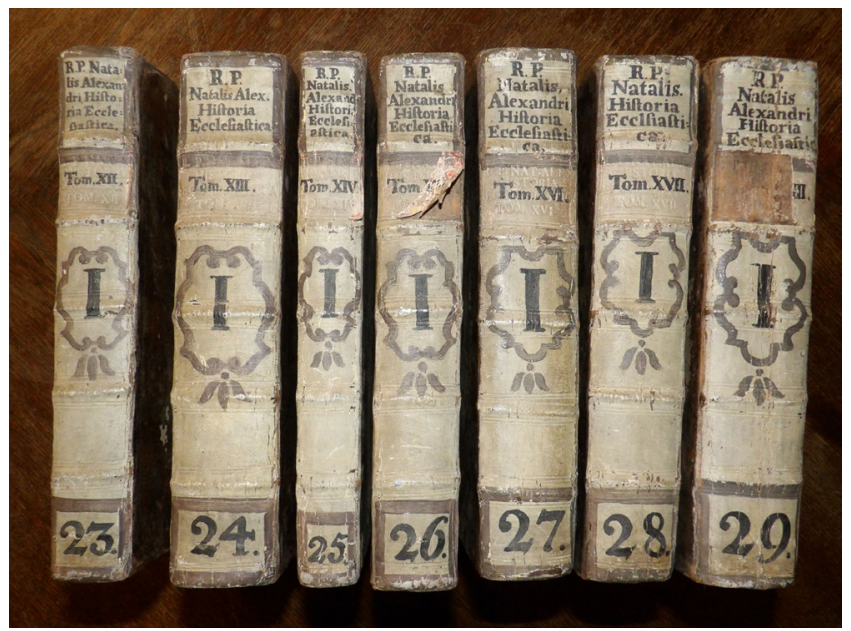

Obr. 2. Vazby knih zakoupených pro klášterní knihovnu mnichovohradištských kapucínů v roce 1780 z finančních prostředků fundace Marie Markéty hraběnky z Valdštejna, rozené Černínové (1689-1725). 


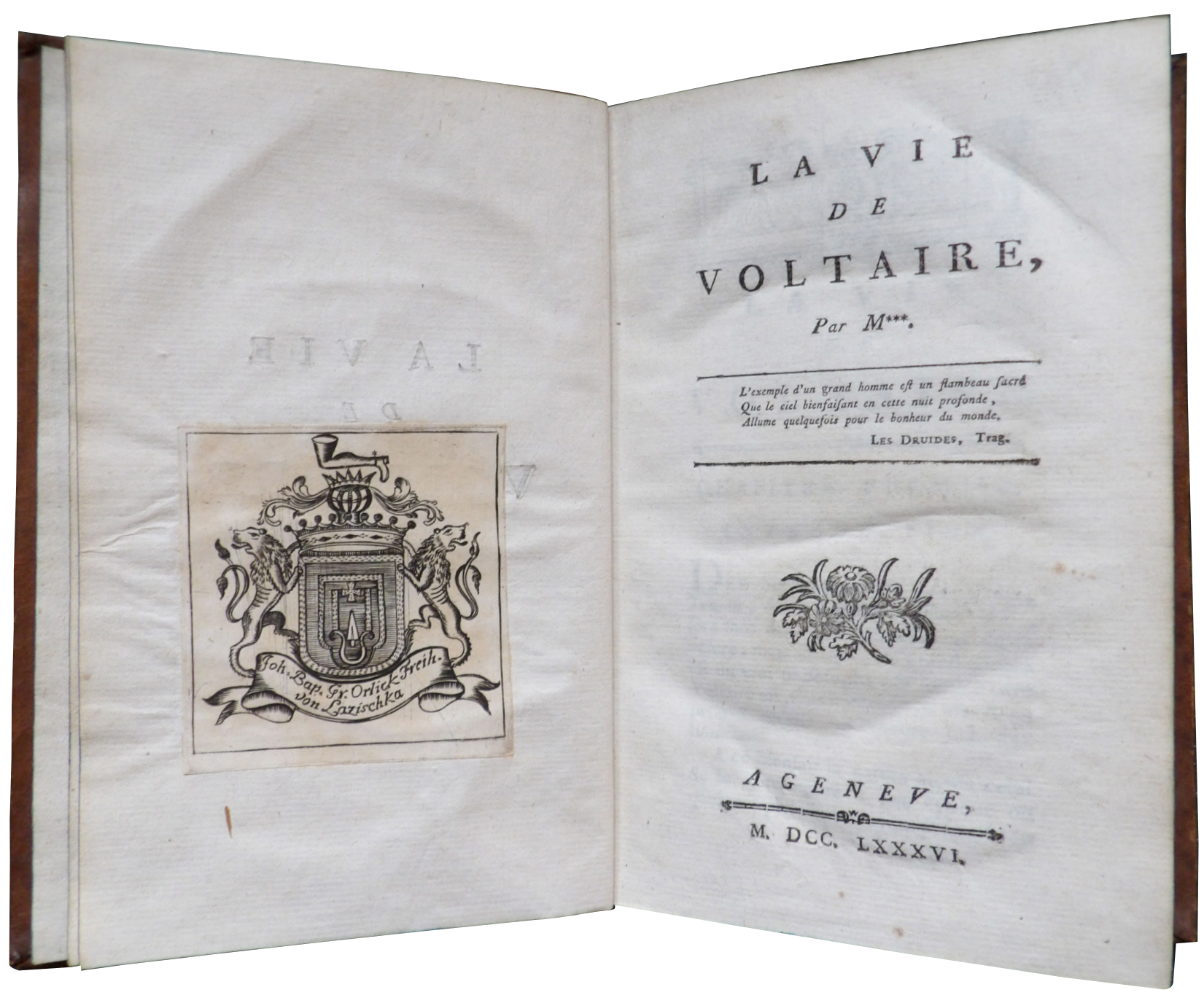

Obr. 3. Grafické exlibris Johanna Baptisty hraběte Orlika z Laziska (1750-1811) ve Voltairově životopisu vydaném v Ženevě roku 1786.

Franze Phillipa von Lamberga. Zakoupeny byly od pražského antikváře Jana Placáka, který dále nabídl soubor 52 drobných náboženských tisků z pozůstalosti Rudolfa Hlavy, a to včetně Knihy hosti̊, obsahující vedle podpisů návštěvníků u semilského sběratele i kresby či vlepené tiskopisy. Tuto kolekci v závěru roku ještě doplnil o 27 tištěných modliteb z 19. století stejné provenience.

Provenienčně neidentifikovatelný soubor 94 kramářských tisků především z padesátých a šedesátých let 19. století byl zakoupen od antikváŕe Jana Schicka z Prahy.

Darem se podařilo získat od Ladislava Dědečka z Prahy celkem 269 náboženských a kramářských tisků z 19. a 20. století, dále pak od Vladimíra Javůrka 2 špalíčky kramářských tisků s písněmi z dvacátých až šedesátých let 19. století v lidové vazbě.

Bohužel na zakoupení mimořádně cenného souboru rukopisných modlitebních knížek z pozůstalosti Rudolfa Hlavy se nepodařilo v roce 2020 získat dotaci Ministerstva kultury ČR, i přesto byla kolekce rukopisných modlitebních knih v Knihovně NM rozšířena, a to darem německy psané modlitební knihy s texty Johanna Pousara - Der Geist im Geiste der Andacht mit Gott dem Schoepfer vereinigt, z doby kolem roku 1900 od Magdalény Veckové z Prahy.

Koncepčním cílem oddělení knižní kultury je dokumentovat současnou tvář české knižní kultury. Proto byl zakou- pen soubor 18 linorytových štočků od významného grafika Pavla Piekara, které vznikly v roce 2020, konkrétněji se jedná o 7 štočků pro barevný soutisk - grafický list František Kupka a 11 štočků pro barevný soutisk - grafický list Rudolf II. s nátisky.

V tomto smyslu je obohacující rovněž zakoupená ilustrační tvorba Libora Beránka, realizovaná pro knihu Jany Pažoutové Ohnivá mise, popisující úmyslné zapálení Prahy $\mathrm{v}$ roce 1689 . Knihu vydalo nakladatelství Olympia v roce 2019.

Pro cenný fond moderní české ilustrace byla učiněna nabídka 22 originálních koláží současného kolážisty Pavla Holeky z Prahy, které připravil pro knihu Hebrejská abeceda: mezi dvěma světy, vyšlé v nakladatelství Arbor vitae v roce 2009. Silně duchovně promyšlený výtvarný soubor k jednotlivým písmenům hebrejské abecedy obdržel v roce 2010 ocenění v kategorii učebnice soutěže nejkrásnější české knihy roku, kterou každoročně vyhlašuje Památník národního písemnictví. Nabídka byla projednána a schválena Centrálním Poradním sborem pro sbírkotvornou činnost NM, ale její zakoupení bylo odloženo na rok 2021.

Stejně tak čeká nabídka souboru 10 uměleckých knižních vazeb z let 1996 až 2019 Elišky Čabalové z Ostravy, jedné z nejlepších uměleckých knihařek, jejíž dílo je vysoce oceňováno a respektováno nejen u nás. Zakoupení souboru 


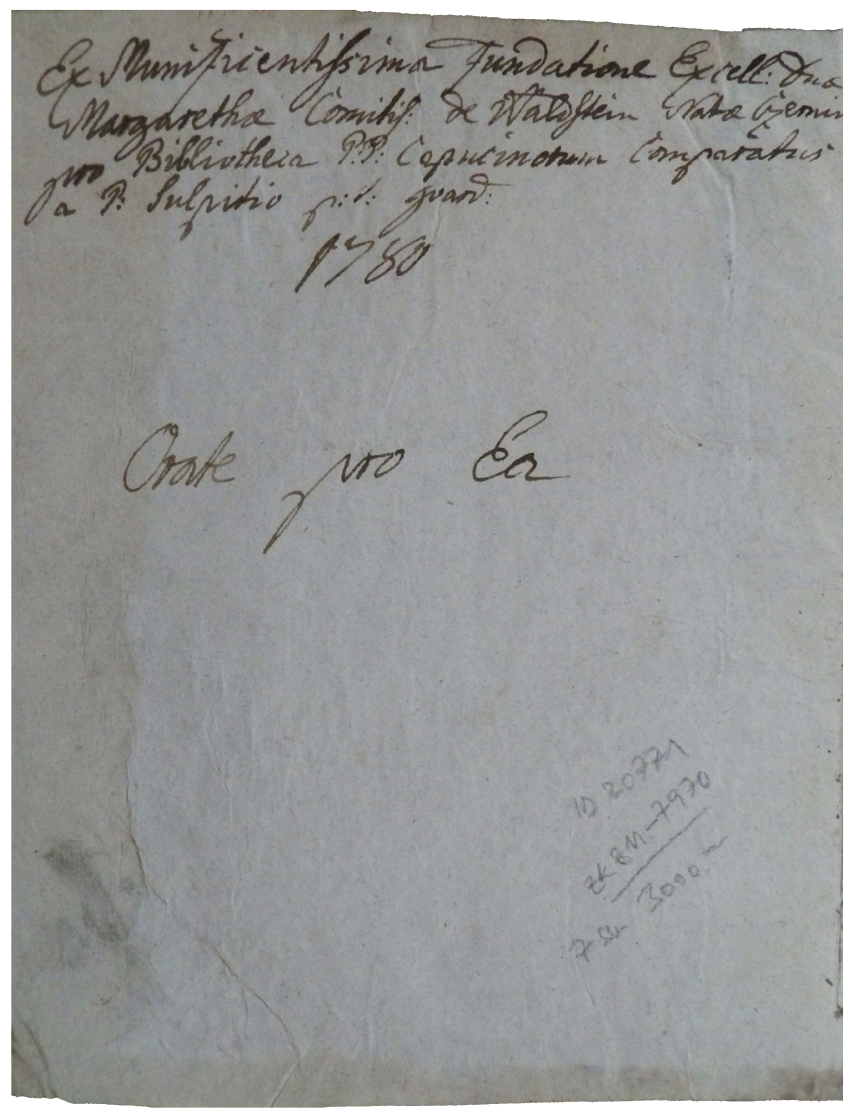

Obr. 4. Zápis o nákupu knih kvardiánem otcem Františkem Sulpiciem Chariem (1735-1789) roku 1780 z prostředků fundace Marie Markéty hraběnky z Valdštejna, rozené Černínové (1689-1725).

bude znamenat kvalitativně vhodné doplnění kolekce české umělecké knižní vazby v knižním fondu Bibliofilie. Eliška Čabalová dále věnovala Knihovně NM soubor osobních předmětů Jindřicha Svobody, jejího učitele a nejvýznamnějšího českého uměleckého knihaře druhé poloviny 20. století. Konkrétněji se jedná o soubor 8 štočků k exlibris J. Svobody a jeho rodiny a soubor 6 matric knihařských značek J. Svobody a firemních razítek jeho knihařství z 20. století.

Archivní fondy oddělení knižní kultury byly rozšířeny o dokumentaci k moderní české knižní kultuře, především $\mathrm{k}$ tvorbě ilustrátorů pro děti a mládež. Cenné archiválie jsou výsledkem celoživotní vědecké a výstavní činnosti Blanky Stehlíkové, propagující jedinečnost české knižní kultury doma i v zahraničí.

Knihovna NM dlouhodobě koncepčně sbírá i předměty nezbytné k technologické výrobě tisků. Nově se tak do sbírek podařilo zařadit zinkovou matrici pro tisk titulní strany provládních novin Wiener Zeitung z roku 1891 (13. 1. 1891, číslo 9). Dárce předmětu Martin Vinš uvedl, že matrice byla náhodně nalezena $\mathrm{v}$ zemi.

Knižní celky oddělení knižní kultury byly obohaceny o dvě bibliofilie, vydané u př́ležitosti 500. výročí bitvy u Lipan jako soukromý tisk Ladislava Dědečka st. (výtisky č. 32 a 71). Mimořádným kouskem pro knižní fond Obrození je pak od antikváře Jana Placáka zakoupený tisk Šestero Kázanj postnjch o hřjssjch proti duchu swatému J. R. Khünla v překladu Antonína Marka, který vyšel v Jičíně u naklada-
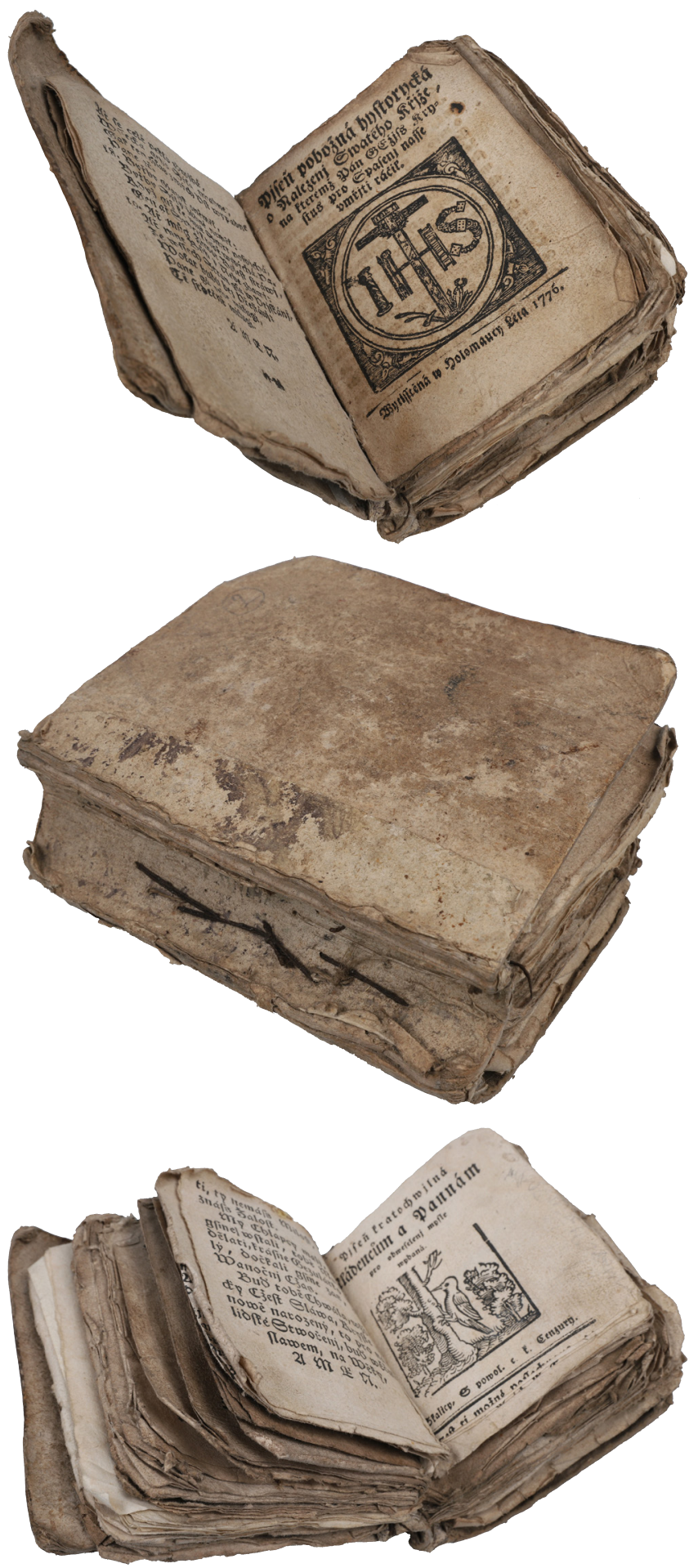

Obr. 5a-5c. Konvolut 57 kramářských písní v původní vazbě. Nejstarší píseň je z roku 1755, nejmladší z šedesátých let 19. století. Sbírka Leopolda Bartoše. Foto: Jan Novotný.

tele Františka Jana Kastránka v roce 1831 . Hodnotu této knihy výrazně zvyšuje dedikace Josefu Jungmannovi.

V oddělení základní knihovny jsou vedle běžné knižní produkce ve výrazném počtu soustředěny knihovny spisovatelů, nakladatelů, vědců, typografů či ilustrátorů. V roce 2020 byly tyto jedinečné knižní celky rozšířeny o soubor knih z osobní knihovny spisovatele Karla Václava Raise a rodiny Raisových (38 titulů), zakoupené od Miruny Raisové z Prahy. 


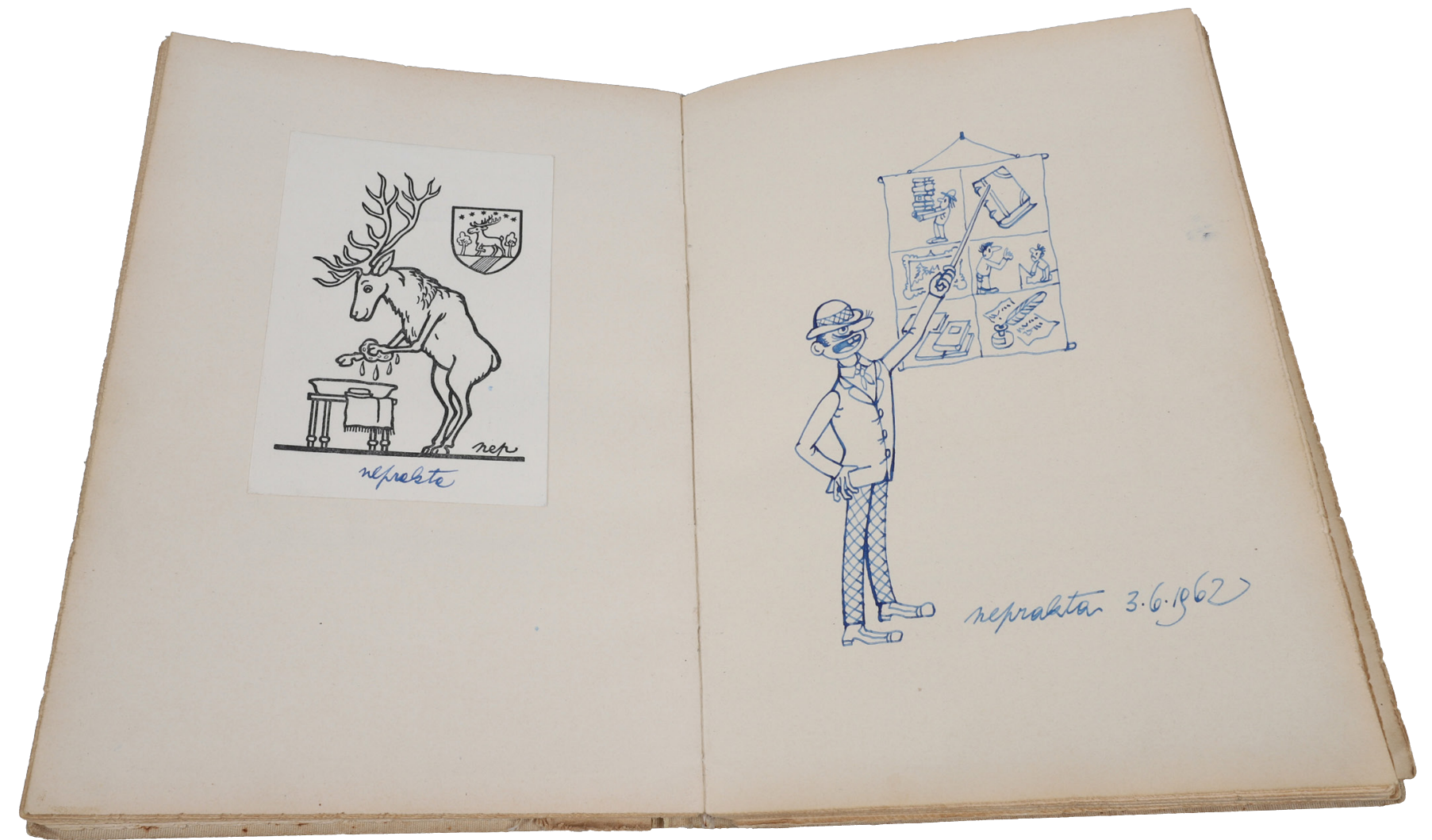

Obr. 6. Kniha návštěv u sběratele Rudolfa Hlavy v Semilech. Foto: Jan Novotný.
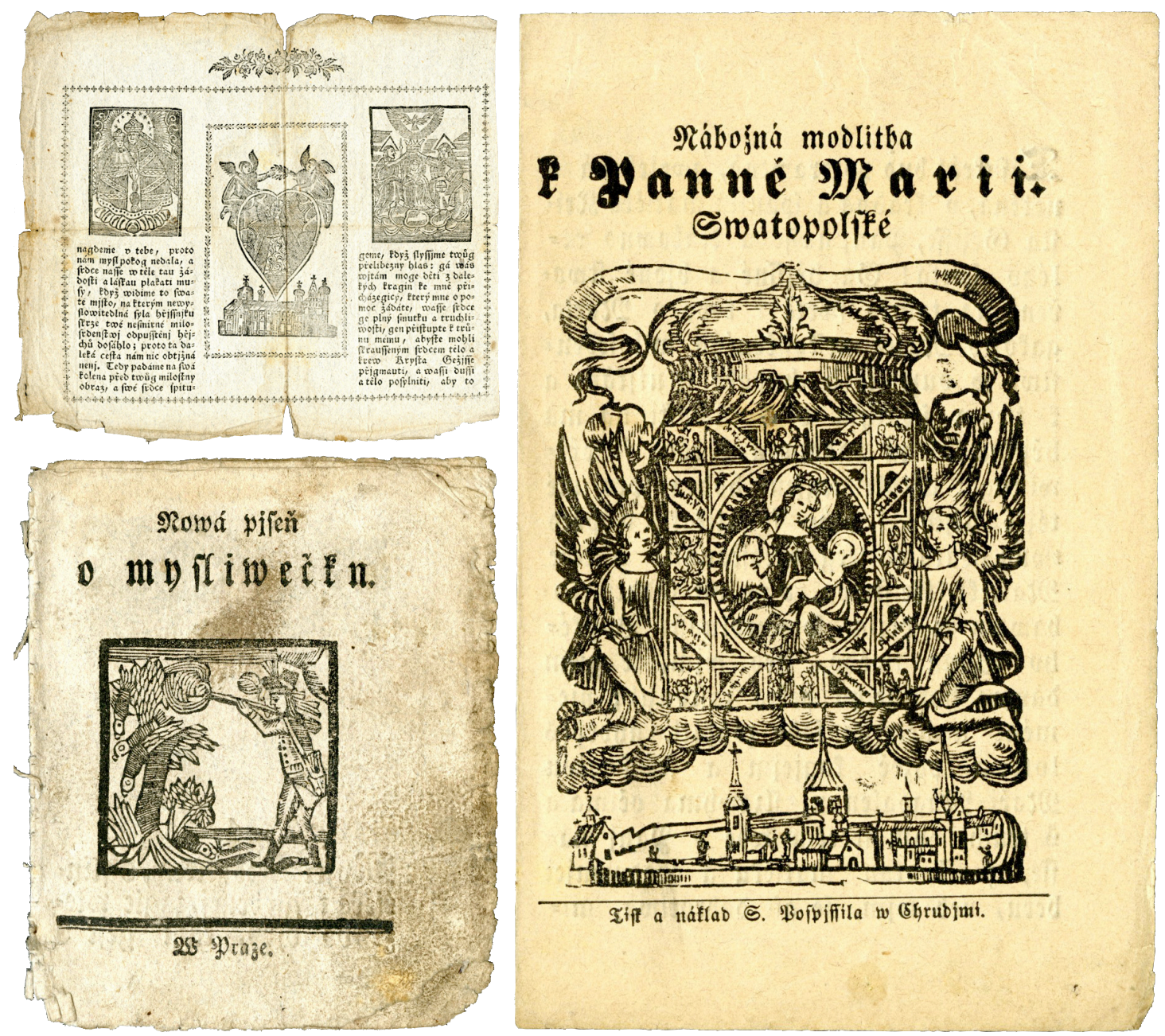

Obr. 7a-7c. Kramářské tisky z 19. století, zakoupené od antikváře Jana Schicka. Foto: Michal Klacek. 


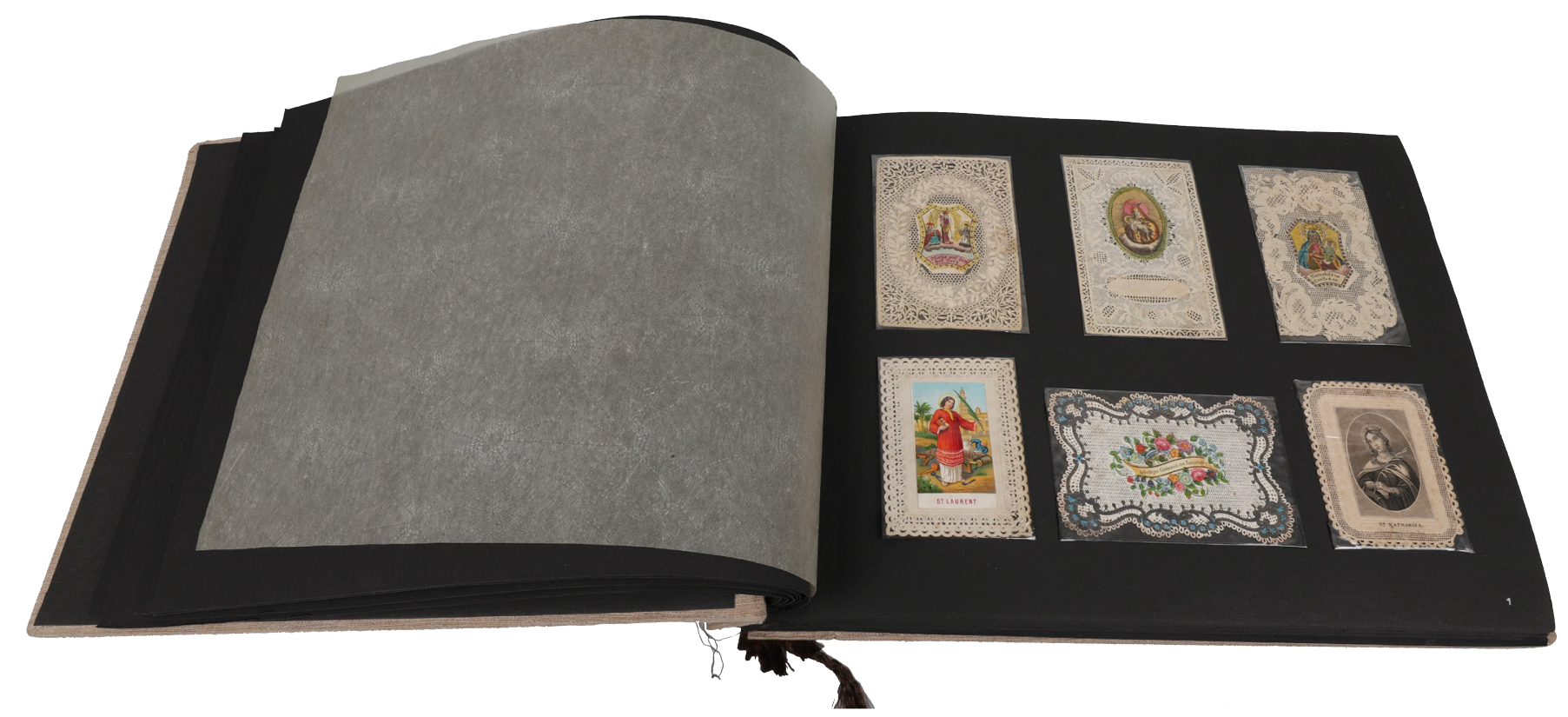

Obr. 8. Album upomínkových tisků a svatých obrázků z 19. a počátku 20. století. Sbírka rodiny Dědečků. Foto: Jan Novotný.

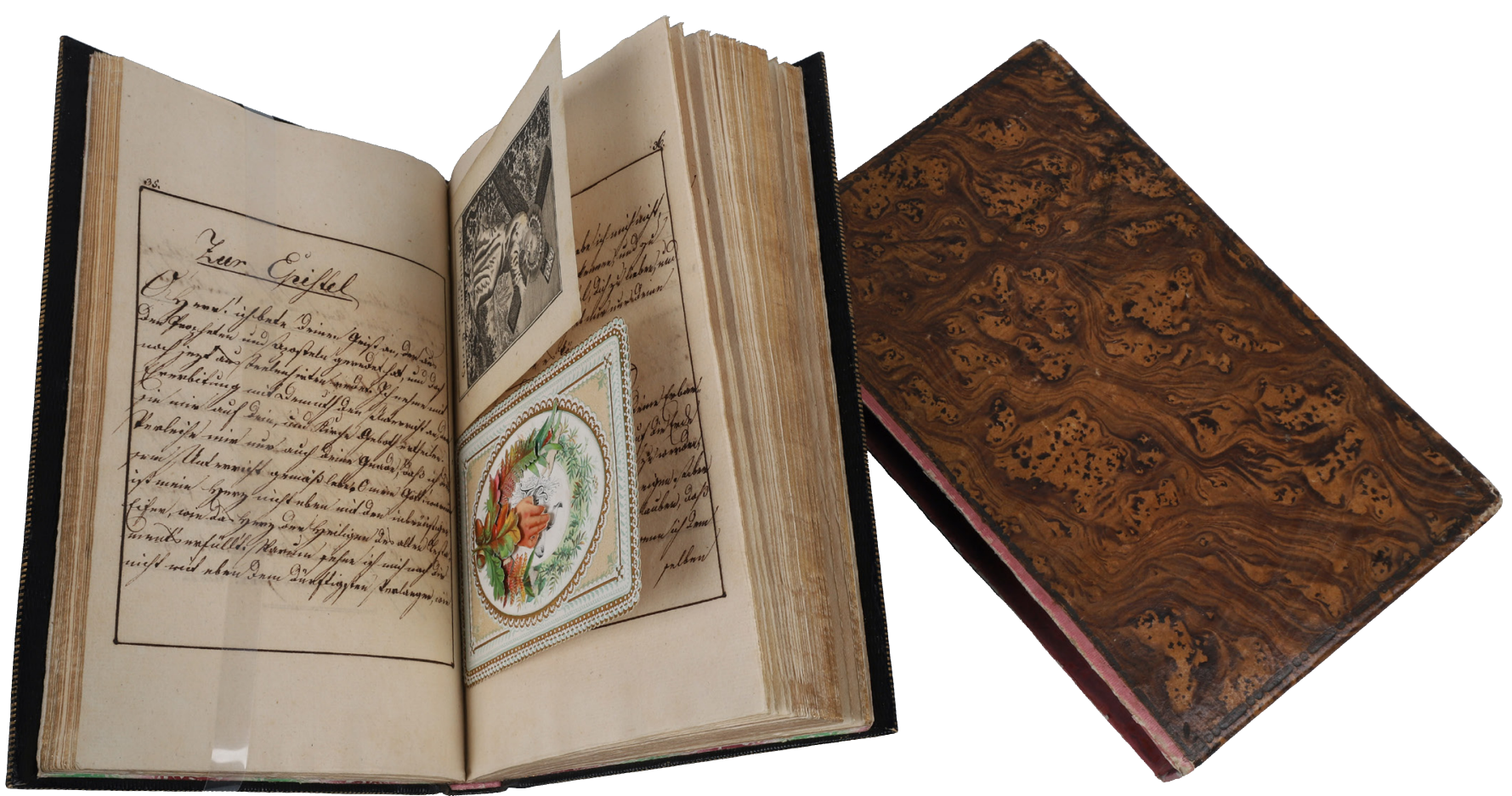

Obr. 9. Rukopisná modlitební knížka z 19. století v originální krabičce. Obsahuje německy psané modlitby a písně. V knížce jsou vloženy svaté obrázky. Dar Magdalény Veckové. Foto: Jan Novotný. 

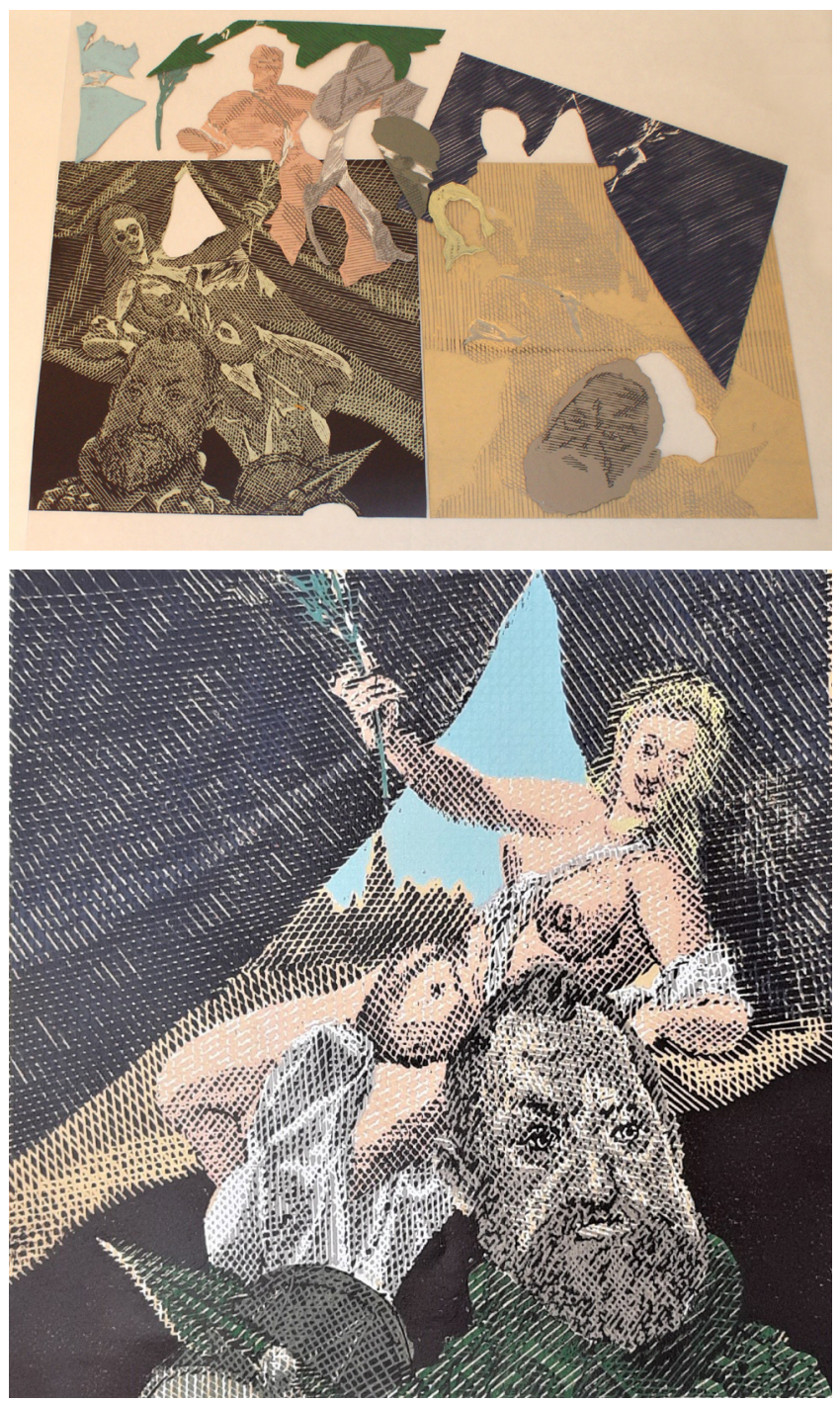

Obr. 10a-10b. Linorytové štočky Pavla Piekara k barevnému soutisku grafického listu Rudolf II. z roku 2020 s nátiskem. Foto: Veronika Karfusová.
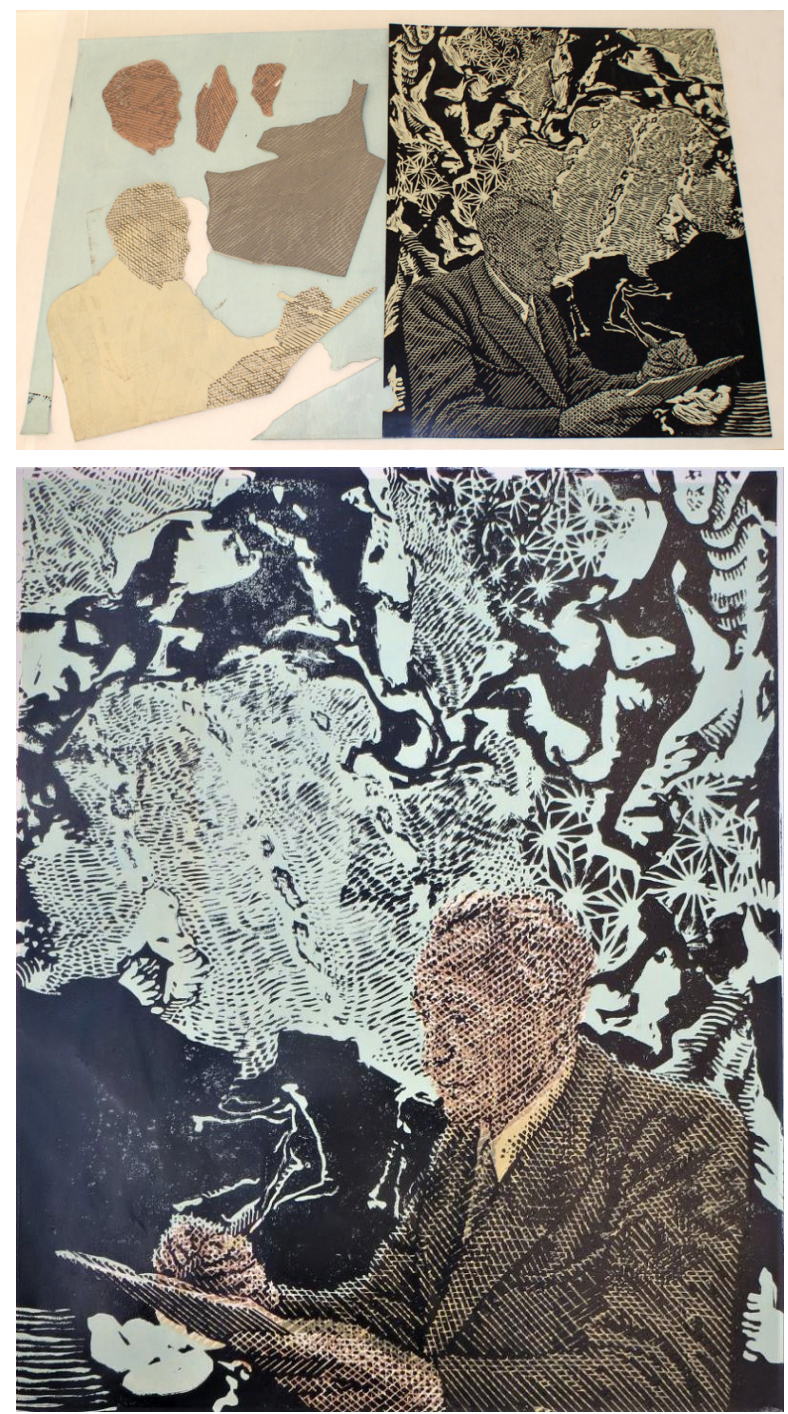

Obr. 11a-11b. Linorytové štočky Pavla Piekara k barevnému soutisku grafického listu František Kupka z roku 2020 s nátiskem. Foto: Veronika Karfusová.
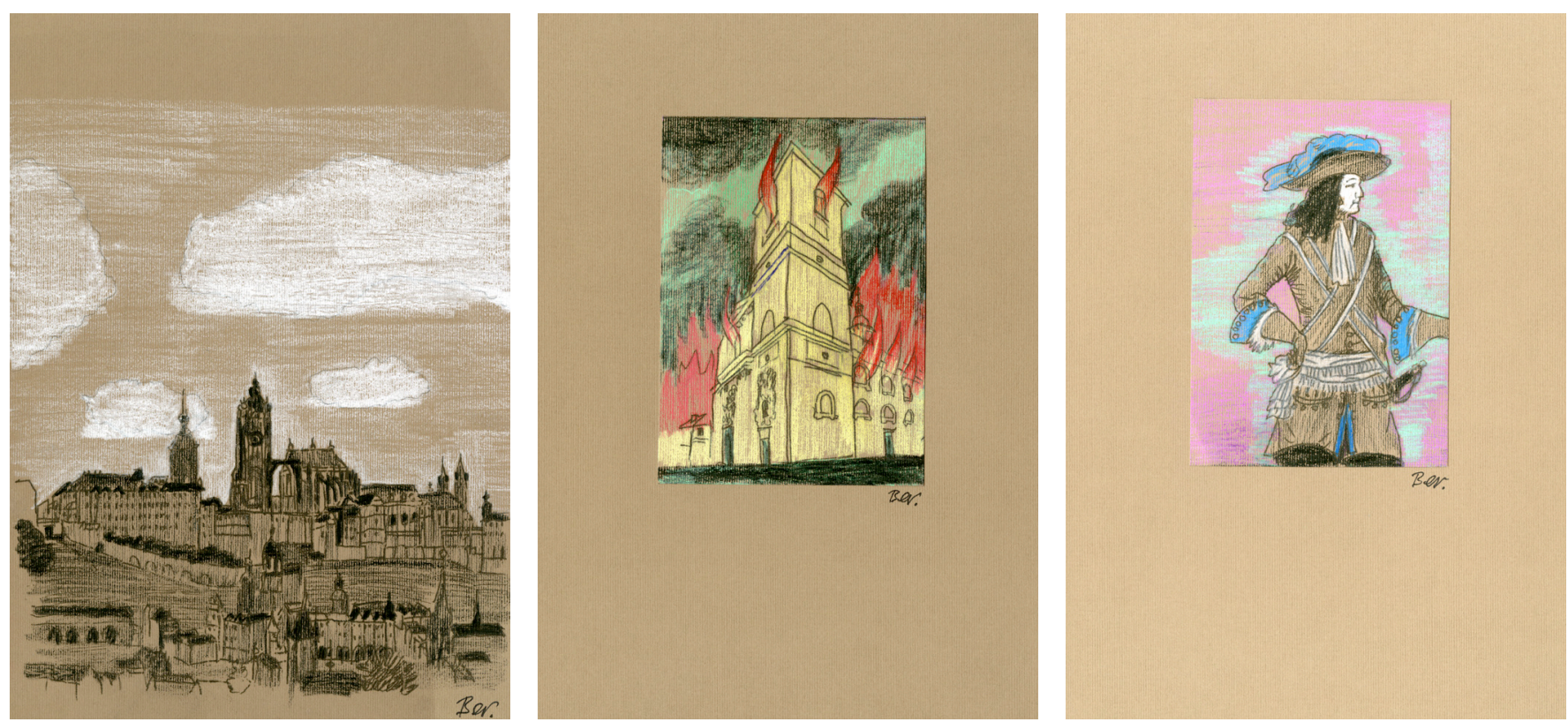

Obr. 12a-12c. Ilustrace Libora Beránka ke knize Jany Pažoutové Ohnivá mise, Olympia, 2019. Foto: Pavel Muchka. 

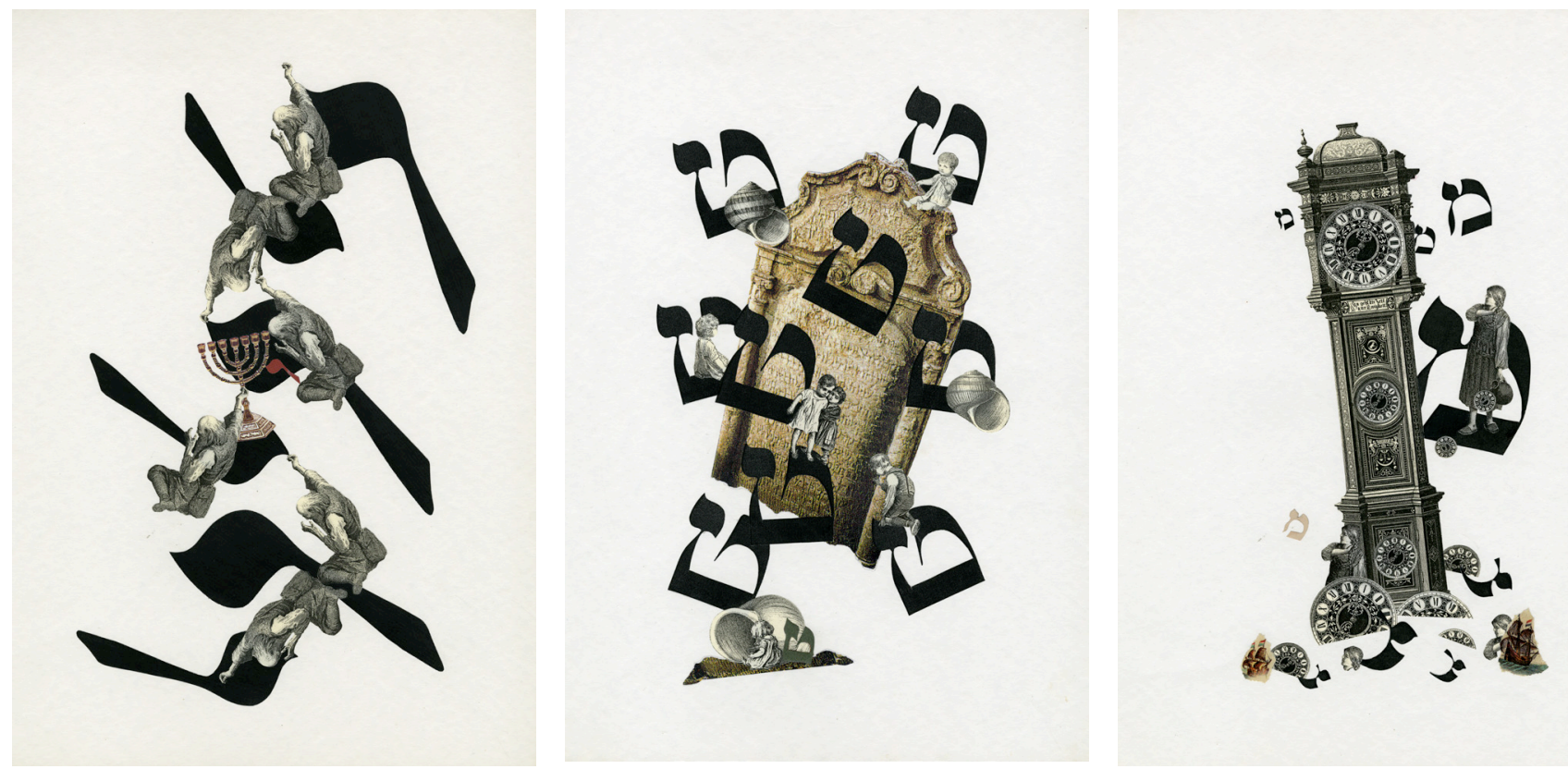

Obr. 13a-13c. Originální koláže Pavla Holeky pro knihu Hebrejská abeceda: mezi dvěma světy, Arbor vitae, 2009. Foto: Pavel Muchka.

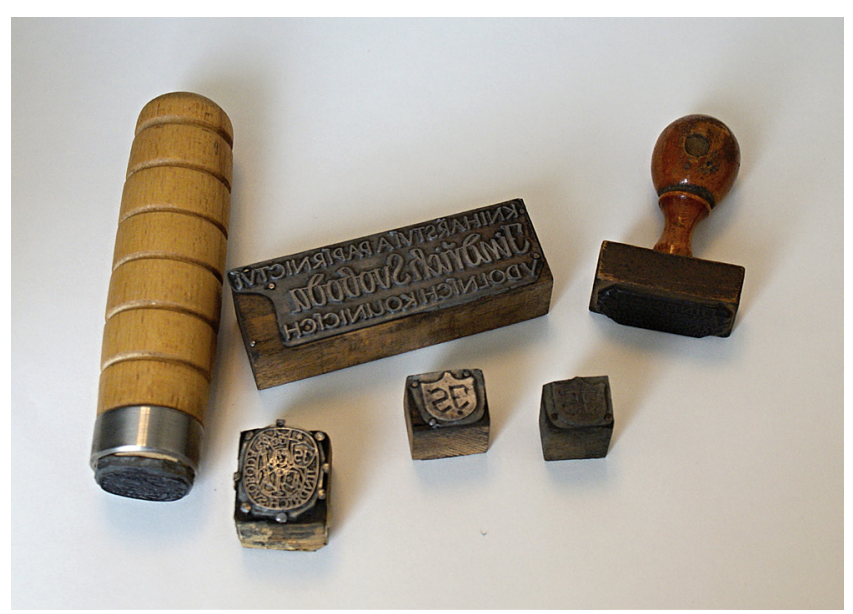

Obr. 14. Soubor matric knihařských značek Jindřicha Svobody a firemních razítek jeho knihařství z 20. století, který darovala Eliška Čabalová. Foto: Veronika Karfusová.

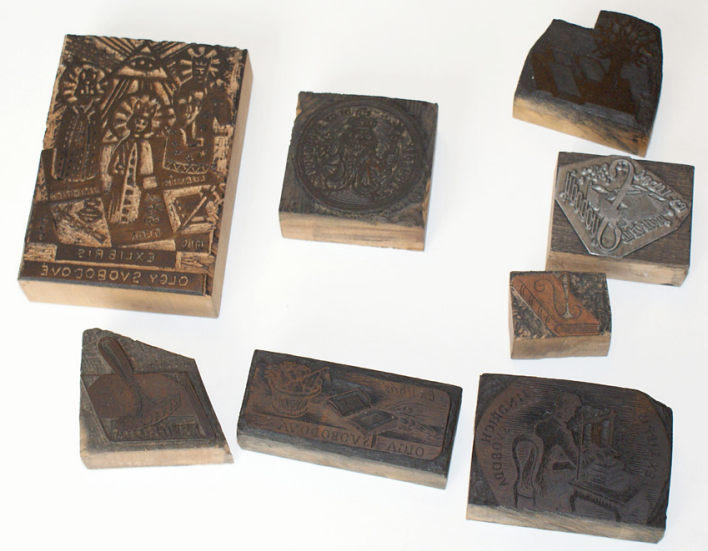

Obr. 15. Soubor štočků k exlibris Jindřicha Svobody a jeho rodiny, získaný darem od Elišky Čabalové. Foto: Veronika Karfusová.

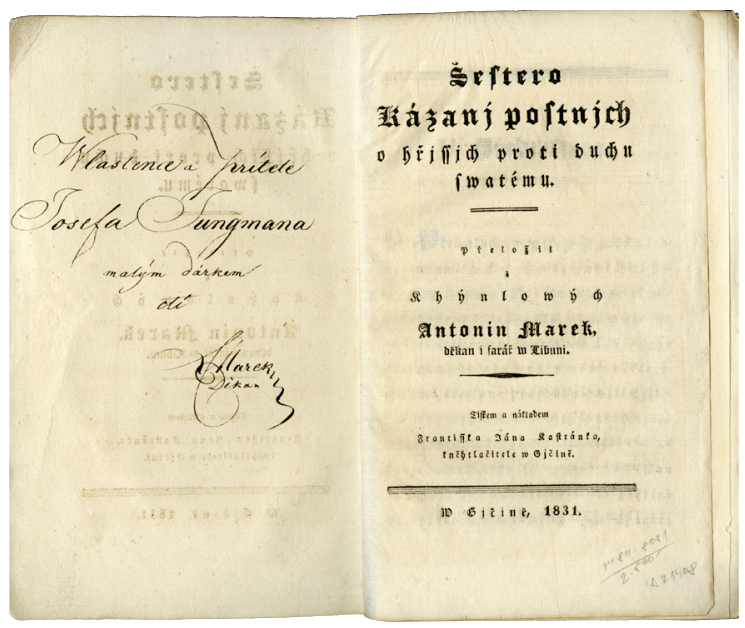

Obr. 16. Kniha Šestero Kázanj postnjch o hřjssjch proti duchu swatému byla věnována Antonínem Markem Josefu Jungmannovi. Koupě od Jana Placáka. Foto: Pavel Muchka. 


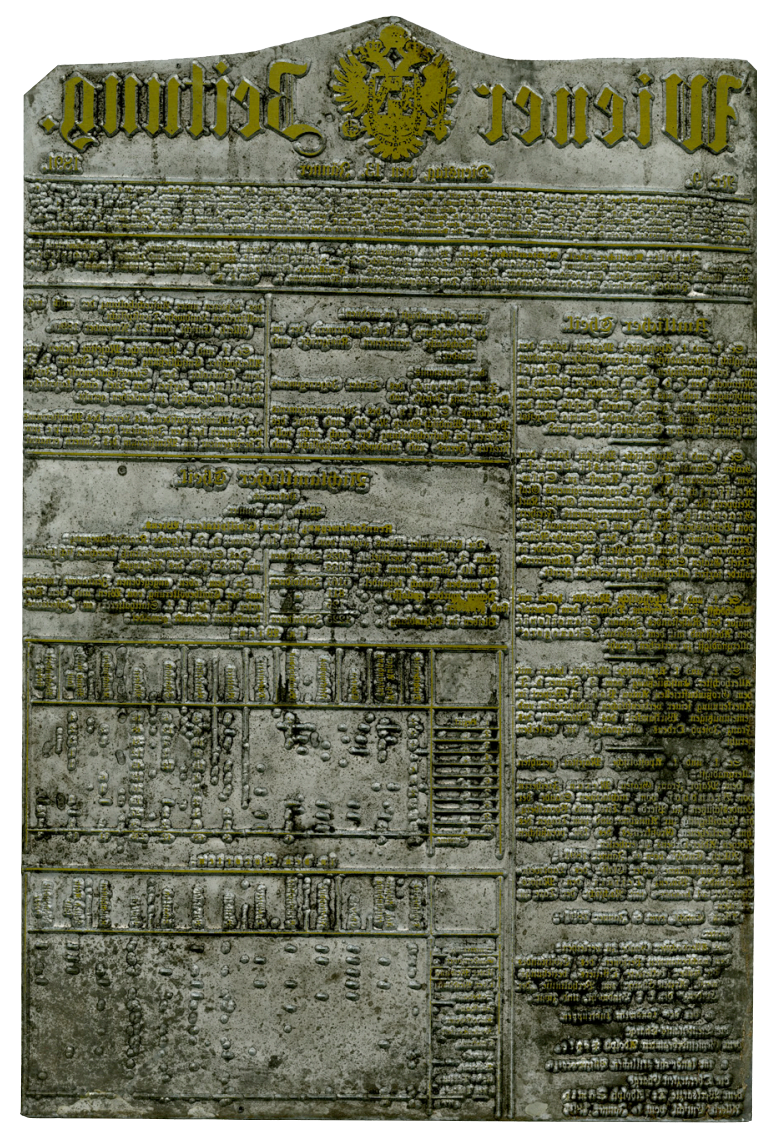

Obr. 17. Zinková matrice pro titulní stranu novin Wiener Zeitung z 13. 1. 1891, věnovaná Martinem Vinšem. Foto: Pavel Muchka.

\section{Pavel Muchka}

Knihovna Národního muzea

oddělení knižní kultury

Vinohradská 1

11000 Praha 1

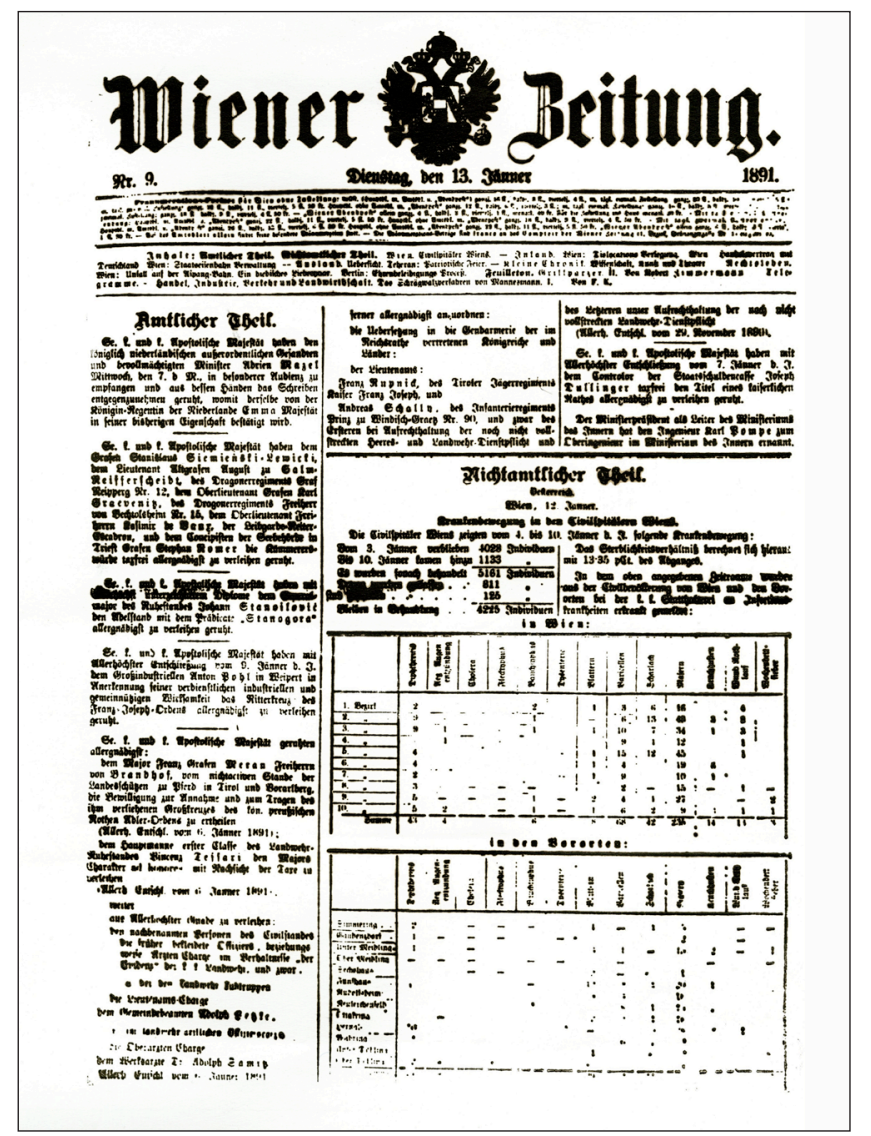

Obr. 18. Nátisk zinkové matrice pro titulní stranu novin Wiener Zeitung z 13. 1. 1891. Foto: Veronika Karfusová.

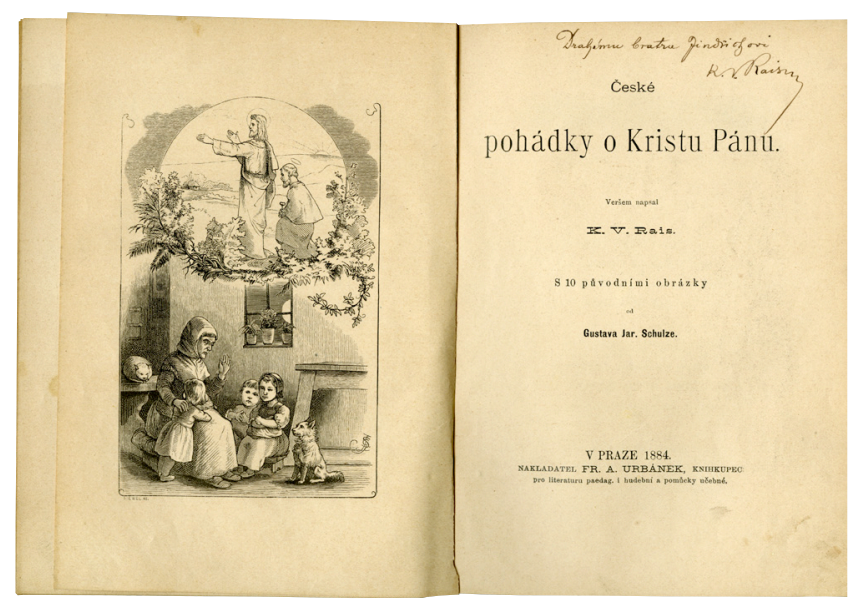

Obr. 19. Fragment knihovny spisovatele Karla Václava Raise, zakoupený od potomků Raisových. Foto: Pavel Muchka. 